\title{
APPLICATION OF WORLDVIEW-3 DATA IN ALTERATION MINERAL MAPPING IN CHADORMALU AREA, CENTRAL IRAN
}

\author{
Z. Karimzadeh *, M. H. Tangestani \\ Department of Earth Sciences, Faculty of Sciences, Shiraz University, Shiraz, Iran - (karimzadeh-shu, tangstan)@ shirazu.ac.ir
}

KEY WORDS: WorldView-3, mineral mapping, band ratio, large scale map, geology, Chadormalu.

\begin{abstract}
:
WorldView-3 (WV-3), launched in August 2014, is a commercial imaging satellite with high spatial resolution that measures reflected radiation in VNIR-SWIR regions in 16 bands. The main objective of this study was to discriminate the alteration minerals in Chadormalu iron deposit area, central Iran, using band ratio techniques on the selected bands of this satellite. To identify the appropriate band ratios the spectral bands of WV-3 were investigated and assessed. Regarding to $\mathrm{Fe}^{3+}, \mathrm{Fe}^{2+}, \mathrm{Al}-\mathrm{OH}, \mathrm{Fe}-\mathrm{OH}, \mathrm{Mg}-\mathrm{OH}$ and $\mathrm{CO}_{3}{ }^{2-}$ spectral absorption features, band ratios B5/B2, B13/B9, B13/B14 and B14/B16 were proposed for enhancement of ferrous and ferric iron bearing minerals, sericite, epidote, chlorite, and dolomite. Combination of field observations, geological map and high resolution spectra of rock samples were used to verify the results. Band ratio B5/B2, B13/B9, B13/B14 gray scale images respectively illustrated that $\mathrm{Fe}^{3+}$-rich minerals are occurring in granite, the $\mathrm{Fe}^{2+}$-rich minerals are enhanced in iron ore, green schist, and diorite units, and sericite is occurring in hydrothermally altered granite and iron ore. Since the $\mathrm{Fe} / \mathrm{Mg}-\mathrm{OH}$ vibrational mode in chlorite-epidote and spectral absorption feature of $\mathrm{CO}_{3}{ }^{2-}$ in dolomite occur in B16, the B14/B16 ratio highlighted chlorite-epidoterich green schist, diorite and dolomitic marble. The false color composite image of B13/B14, B13/B9, and B14/B16 as RGB produced a large scale map which successfully discriminated the rock types and accompanying alteration minerals. This study demonstrated that WV-3 data have efficient spectral resolution to discriminate alteration minerals with $\mathrm{Fe}^{3+}, \mathrm{Fe}^{2+}, \mathrm{Al}-\mathrm{OH}$ and $\mathrm{Fe} / \mathrm{Mg}-\mathrm{OH}$ or $\mathrm{CO}_{3}{ }^{2-}$ spectral absorption features.
\end{abstract}

\section{INTRODUCTION}

Remote sensing techniques provide information on the characteristics of the exploration target surfaces. Hydrothermal alterations produce distinctive assemblages of minerals considering the location, degree and longevity of alteration processes. Alteration minerals play significant role in prospecting of economic deposits and can be mapped by remote sensing when exposed at the surface of the earth. Electronic transitions and molecular vibrations in the mineral lattices lead to form spectral absorption features in visible near infrared (VNIR) and short wave infrared (SWIR) ranges. Spectral absorption features of minerals which are well documented can be used to map minerals using multispectral data (Hunt et al., 1972; Hunt, 1977; Rowan and Mars, 2003). WorldView-3 (WV-3), launched in August 2014, is a commercial satellite owned and operated by Digital Globe Inc, which has opened up new opportunities to map mineral assemblages, vegetation cover, and man-made materials (Kruse \& Perry, 2013). WV-3 is a multispectral sensor with high spatial resolution that measures reflected radiation in eight VNIR bands from 397 to $1039 \mathrm{~nm}$ and in eight SWIR bands from 1184 to $2373 \mathrm{~nm}$ (Table 1). There are few published researches in mineral and lithological mapping using WV-3 multispectral data. For instance, WV-3 SWIR data was examined on the Cuprite site for mineral mapping including kaolinite, alunite, buddingtonite, muscovite, calcite, and hydrothermal silica (Kruse et al., 2015). WV-3 VNIR-SWIR data have been assessed for lithological mapping at Cuprite, Nevada (Johnson and Koperski, 2017) and Pobei area of the Xinjiang Uygur Autonomous Region, China (Ye et al., 2017), which provided detailed target and classification map at large scale with appropriate ground truth. A comparison between classification accuracy of WV-3, ASTER and OLI/Landsat- 8 data in Pobei area of the Xinjiang Uygur
Autonomous Region, China, showed that the accuracy coefficient of WV-3 data was respectively $17 \%$ and $14 \%$ higher than utilized ASTER and OLI /Landsat- 8 data. The high spatial resolution of WV-3 data and its more diagnostic absorption features thanks to its SWIR bands is the reason of this high accuracy coefficient (Ye et al., 2017). Another research at this study area for extracting alteration minerals by using WV-3 data demonstrated that the WV-3 data can successfully distinguish Al-OH-bearing from $\mathrm{Mg}-\mathrm{OH}-$ bearing alteration (Sun et al., 2017). The ability of WV-3 VNIR data in mapping iron oxide/hydroxide minerals of iron caps associated with the porphyry copper mineralization has been investigated at a porphyry copper deposit, in the northeastern Isfahan, Iran (Salehi and Tangestani, 2018). Mineral mapping capability of WV-3 data has been investigated at Mountain Pass, California. In this research, by using true- and false-color composite images, band Ratios, and Logical Operator Algorithms, the Al$\mathrm{OH}, \mathrm{Fe} / \mathrm{Mg}-\mathrm{OH}$ and $\mathrm{CO}_{3}{ }^{2-}$ bearing minerals have been detected (Mars, 2018). A separation of alunite and buddingtonite via subtle differences in spectral signatures in WV-3 16 band has been demonstrated at Cuprite, Nevada, USA (Baugh and Gow, 2018). The capability of WV-3 in mineral mapping has been evaluated at Rodalquilar, Spain and has been compared with Hymap and ASTER (Hewson et al, 2018). All of these works have proved the capability of WV-3 data in both feature classification and information extraction. This research, for the first time, shows how band ratios of WV-3 data from Chadormalu area, central Iran, can be used to map alteration minerals associated with an iron oxide-apatite deposit, and its surroundings.

\section{GEOLOGICAL SETTING}

The Chadormalu area is located approximately $180 \mathrm{Km}$ NE of Yazd (Fig. 1), in a semi-arid to arid district. Field observations

* Corresponding author 
indicated that thorn bushes cover approximately 10 to $20 \%$ of the surface.
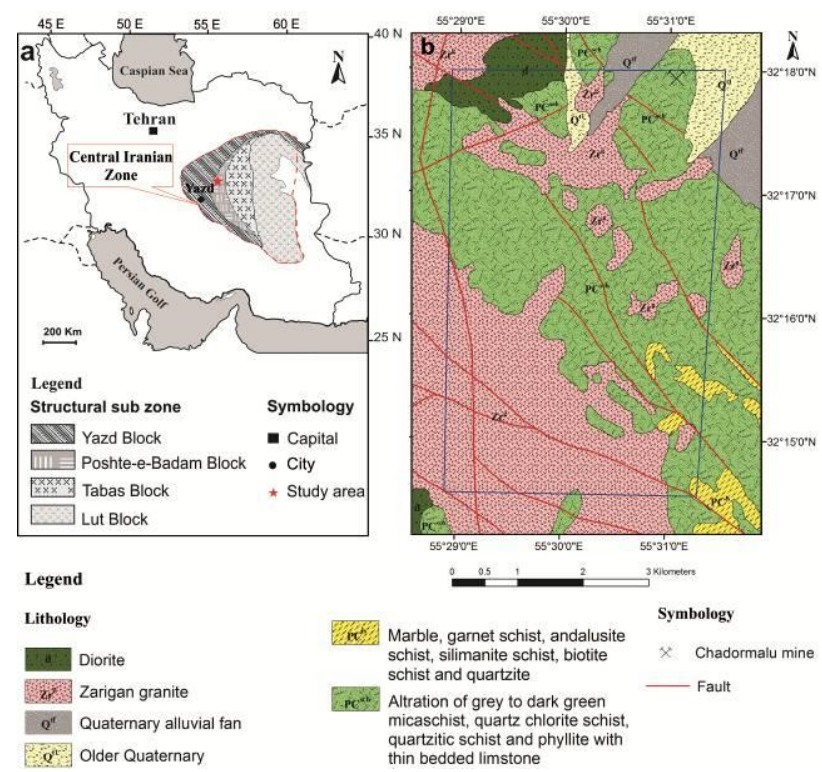

Fig. 1. a. Iran map with simplified structural subzone of central Iran (after aghanabati, 1998) and location of Chadormalu area, dashed red line shows the approximate region of central Iranian zone. b. Geological map of study area, modified after 1:100000 geological map of Ariz (Majidi and babakhani, 2000) and 1:100000 geological map of Chadormalu (Ghaemi and Saidi, 2006). The WV-3 area of interest (AOI) is restricted to blue borderline.

Chadormalu iron oxide-apatite deposit is located in central Iranian structural zone. Central Iranian structural zone is the intra part of Iran plateau (Fig. 1a). It is a fragment of Gondwana with a Precambrian basement (Forster and Jafarzadeh, 1994; Ramezani and Tuker, 2003). This zone is content of one of the most important metallogenic provinces of Iran and the biggest iron oxide-apatite deposits such as Chadormalu, Choghart and Se-Chahun respectively with 400, 216 and 140 million tons iron ore, are placed in this zone (Daliran, 2009).

This area is geologically consisted of metamorphosed mafic rocks and the gneissic granite of the late Precambrian, namely Tashk Formation, and intrusive rocks (mostly granite and locally diorite and gabbro-diorite dikes/sills) which are intruded into the Precambrian sequences of Tashk Formation. The granitic intrusion, formally named Zarigan Granite, is abundant in this metallogenic province, and is occurring western of the study area (Fig. 1b). Dikes of granite porphyry, syenite porphyry, diabase as well as rhyolite and dacite are also abundant in the region. Metamorphosed rocks are generally comprised of green schist, chlorite schist, garnet mica schist, quartzite schist, phyllite, gneiss, marble, and quartzite, which are cropped out in eastern the study area from north to south (Fig. 2a).

The oblique slip to strike slip faults generally trend NW-SE, while the thrust faults are trending E-W and NE-SW (Ramezani and Tuker, 2003) (Fig. 1b).

Chadormalu iron oxide-apatite deposit, with 400 million tons iron, $55 \%$ mean grade of $\mathrm{Fe}$ and $2.5 \%$ grade of $\mathrm{P}_{2} \mathrm{O}_{5}$ is one of the biggest iron deposits of Iran (Forster and Jafarzadeh, 1994; Torab, 2008) which is placed at northeastern part of WV-3 data frame coverage. Types of alterations have affected the host rock of this deposit (Fig. 2): potassic alteration as forming Kfeldespare (orthos- microcline), sodic alteration (albitization), calsic alteration (actinolitization), silisification, carbonatization and iron oxide metasomatism. Albitization has strongly acted on rhyolites in the deposit (Fig.2.b). Oxidation zone is recognized at the depth of $1500 \mathrm{~m}$ as primary martitization to entirely substitution of magnetite by martite (secondary hematite).

Granitic rocks of the study area are strongly covered by desert varnish (Fig.2c).

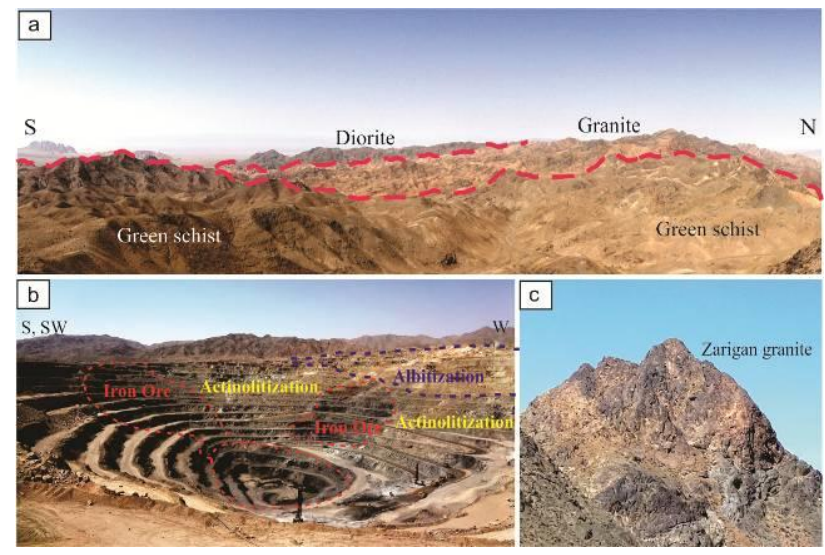

Fig. 2. Landscape views of rock units and alteration at Chadormalu area, central Iran. a. View of green schist, granite and diorite in the study area from an elevation of about 2000 meters above sea level. b. Southern to western part view of

Chadormalu iron-apatite mine with albitization and actonilitization alteration zones. c. Zarigan granite with cover of desert varnish.

\section{MATERIALS AND METHODS}

\subsection{WorldView-3 data}

WV-3 has PAN and VNIR multispectral bands with $0.31 \mathrm{~m}$ and $1.24 \mathrm{~m}$ spatial resolution, respectively, and supplemented by 8 short wave infrared (SWIR) bands ranging from approximately $1.2 \mu \mathrm{m}$ to $2.33 \mu \mathrm{m}$ with $3.7 \mathrm{~m}$ spatial resolution (Table 1 ). The commercially available products of this satellite are resampled to $0.5 \mathrm{~m}$ (PAN), $2 \mathrm{~m}$ (VNIR) and $7.5 \mathrm{~m}$ (SWIR). The sensor also provides an additional 12 bands of Clouds, Aerosols, water Vapor, Ice and Snow (CAVIS) in $30 \mathrm{~m}$ resolution for atmospheric compensation (WorlView-3 data sheet, 2014; Kruse \& Perry, 2013).

In terms of spectral bands, WV-3 surpasses the ASTER data. In the VNIR range, WV-3 has several additional bands which potentially enables mapping of iron oxides more accurately. The 1.200-1.750 $\mu \mathrm{m}$ region is covered by 4 SWIR bands in WV-3 while ASTER has only one band in this region. Bands 13 to 16 of WV-3 (between 2.160-2.330 $\mu \mathrm{m}$; Table 1) are corresponded to bands 5 to 8 (between 2.165-2.330 $\mu \mathrm{m}$ ) of ASTER. However, band 9 of ASTER is not available in the spectral range of WV-3. 


\begin{tabular}{clcc}
\hline Subsystem & WV-3 Bands & $\begin{array}{c}\text { Spectral band } \\
\text { range }(\boldsymbol{\mu m})\end{array}$ & $\begin{array}{c}\text { Spectral band } \\
\text { centre }(\boldsymbol{\mu m})\end{array}$ \\
\hline PAN & & $0.450-0.800$ & 0.649 \\
VNIR & B1: Coastal blue & $0.397-0.454$ & 0.428 \\
& B2: Blue & $0.445-0.517$ & 0.482 \\
& B3: Green & $0.507-0.586$ & 0.547 \\
& B4: Yellow & $0.580-0.629$ & 0.604 \\
& B5: Red & $0.626-0.696$ & 0.660 \\
& B6: Red edge & $0.698-0.749$ & 0.722 \\
& B7: NIR-1 & $0.765-0.899$ & 0.824 \\
& B8: NIR-2 & $0.857-1.039$ & 0.913 \\
SWIR & B9: SWIR-1 & $1.184-1.235$ & 1.209 \\
& B10: SWIR-2 & $1.546-1.598$ & 1.571 \\
& B11: SWIR-3 & $1.636-1.686$ & 1.661 \\
& B12: SWIR-4 & $1.702-1.759$ & 1.729 \\
& B13: SWIR-5 & $2.137-2.191$ & 2.163 \\
& B14: SWIR-6 & $2.174-2.232$ & 2.202 \\
& B15: SWIR-7 & $2.235-2.285$ & 2.259 \\
& B16: SWIR-8 & $2.285-2.373$ & 2.329 \\
\hline
\end{tabular}

Table 1. Spectral resolution and band centres of WorldView-3 (WV-3) data (source: Digital Globe).

The data used in this study were acquired on $2^{\text {nd }}$ April 2015 at 07:01 a.m. and contains 4 standard VNIR bands including B2 (blue), B3 (green), B5 (red), and B7 (NIR-1) and 8 SWIR bands. The utilized data is level $2 \mathrm{~A}$ which already have a systematic radiometric calibration and geometric correction; also, all bands were enhanced to 16 bit.

The SWIR data were spatially resampled to $2 \mathrm{~m}$ and were stacked with the VNIR data. Since the WV-3 data are commercially available as relative radiometrically corrected pixels, they need to be converted into physical quantities such as radiance or reflectance (Kuester, 2016). Absolute radiometric correction software embedded in ENVI 5.3 was employed for converting the WV-3 data to top of atmosphere radiance data. This software uses absolute calculation factor, effective band width, gain, and offset values provided in the metadata file. The WV-3 VNIR-SWIR radiance data were then converted to reflectance using Log residual atmospheric correction (Green and Craig, 1985) software.

\subsection{Band Ratios}

The different spectral characteristics between surface materials that are usually difficult to distinguish in raw images can be enhanced by using ratio techniques and the information obtained by ratio transforms is almost new which is not comparable with the information obtained from the bands independently (Miguel-Ayanz and Biging, 1996). Further such techniques may remove the effect of variable illumination resulting from topographic variations (Mather, 2004).

Regarding to the alteration mineral spectral characteristics, the appropriate band ratios were defined and were applied in this study for discriminating and mapping alteration minerals associated with host rocks of the Chadormalu.

\subsection{Accuracy assessment}

WV-3 band ratio results and mineral map from false color composite ratio bands were validated using a geological map, field observations and spectra of the collected rock samples. Although difference of maps' scale between geological map of the study area and the current mineral map (1:100000 versus 1:4000, respectively) makes little incompatibility in details of rock units, but field observations removed well the uncertainties. About 45 sample spectra were measured from rock units at the laboratory using a NIRs XDS Rapid content analyzer spectrometer in Shiraz University with spectral range of 400-2500 nm. Spectral data were resampled to 12 bands of WV-3 data; besides that image spectra of each WV-3 mineral map units were compiled and visually compared to WV-3 resampled sample spectra taken from the field validation sites (Fig. 8)

\section{RESULTS AND DISCUSSION}

\subsection{Spectral analysis of alteration minerals}

On the basis of geology of the Chadormalu area (Karimzadeh and Tangestani, 2018) and field works, only those minerals present in the altered zone of the study area were selected and their spectral characteristics were visually inspected. The spectra of ferrous and ferric iron rich minerals, sericite, epidote, chlorite, and dolomite from the USGS spectral library were selected and were defined based on the WV-3 spectral bands (Fig. 3). Diagnostic spectral absorption features of these alteration minerals were studied and the appropriate band ratios were identified to recognize the exposure of these minerals in the study area. Band ratio images represent the contrast between specific spectral absorption features of minerals (Vincent, 1997; Rowan and Mars, 2003). Using two bands with high difference in reflectivity, lead to produce a gray scale image with the more extremes of black and white. Dark pixels are characterized by quotient with less than unity. Accordingly, for achieving the target with white signature, the quotient should be more than unity and band with high reflectivity should be adjusted as numerator.

Ferric iron minerals such as goethite and hematite showed a set of broad spectral absorption features caused by crystal field effects centered at approximately $0.50 \mu \mathrm{m}$ and $0.85-0.92 \mu \mathrm{m}$ regions, which are defined by WV-3 bands 2 through 5 and bands 7, 8, and 9, respectively (Fig. 3, goethite and hematite spectra). The absorption $0.66 \mu \mathrm{m}$ is also more marked for goethite than hematite. A false color composite image of WV-3 data with B5 as red, B2 as green and B4 as blue enhanced the ferric iron rich minerals as magenta. According to the WV-3 resampled spectra, band 5/band 2 ratio which makes high difference in reflectivity can be used to highlight ferric iron minerals such as hematite, goethite, and iron oxide/hydroxides components of desert varnish (Fig. 4). 


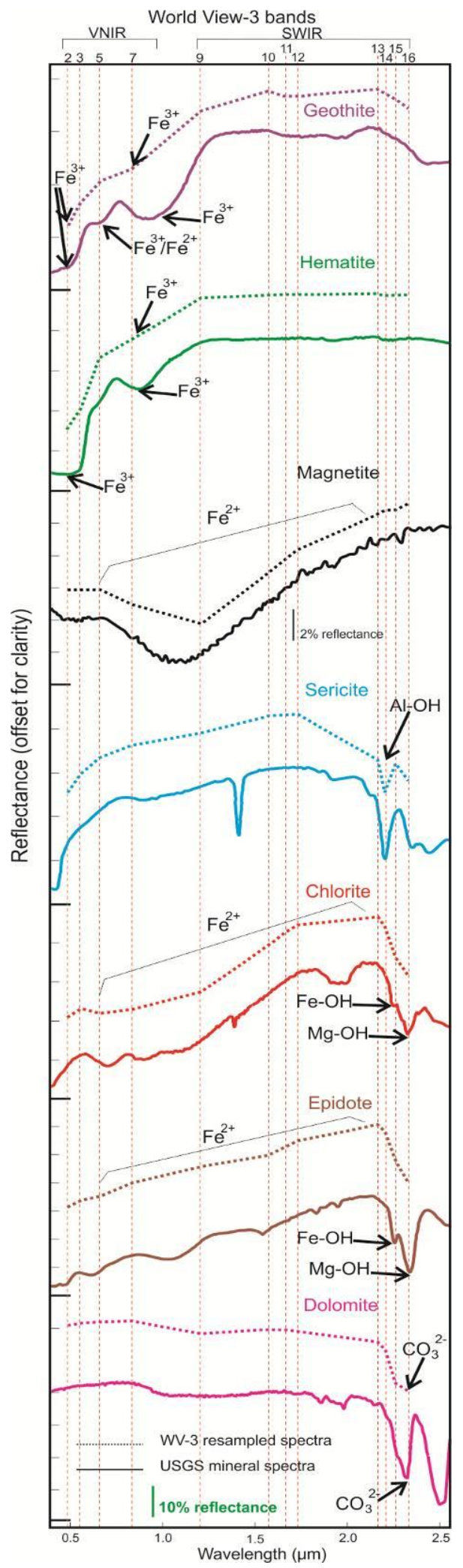

Fig. 3. Spectral pairs of USGS spectral library and WorldView3 (WV-3) resampled spectra. Dotted red lines show positions of WV-3 spectral band centers. Spectral absorption features for $\mathrm{Fe}^{3+}, \mathrm{Fe}^{2+}, \mathrm{Al}-\mathrm{OH}, \mathrm{Fe}-\mathrm{OH}, \mathrm{Mg}-\mathrm{OH}$ and $\mathrm{CO}_{3}{ }^{2-}$ are labeled. Spectra are offset on the vertical axis for clarity; scale showing $10 \%$ reflectance is regarded to all spectra except magnetite which has $2 \%$ reflectance scale. Abbreviations: VNIR = visible near infrared, SWIR = short wave infrared.

Minerals such as magnetite, chlorite and epidote have a weak but distinguishable ferrous iron spectral absorption feature. The ferrous iron feature covers $0.6 \mu \mathrm{m}$ to $2.05 \mu \mathrm{m}$ which is defined by WV-3 bands 3 through 8 and bands 9 through 13 (Fig. 3 , magnetite, chlorite and epidote spectra). The $\mathrm{Fe}^{2+}$ band ratio of band 13/band 9 was used to map ferrous iron-rich minerals (Fig. 5a).

Sericite spectrum from the USGS spectral library shows two strong spectral absorption features, centered at approximately $1.4 \mu \mathrm{m}$ caused by the first overtone of $\mathrm{OH}^{-} / \mathrm{H}_{2} \mathrm{O}$, and from 0.22 $\mu \mathrm{m}$ to $0.222 \mu \mathrm{m}$ which is due to the Al-OH vibrational modes. $\mathrm{Al}-\mathrm{OH}$ absorption feature is defined by WV-3 bands 13,14 , and 15 (Fig. 3, sericite spectra). A band ratio of B13/ B14 was used to map sericite-rich rocks (Fig. 5b).

The USGS spectra of chlorite and epidote show a strong spectral absorption feature near $2.33 \mu \mathrm{m}$ due to $\mathrm{Mg}-\mathrm{OH}$ vibrational mode and a weak absorption feature near $2.25 \mu \mathrm{m}$ due to $\mathrm{Fe}-\mathrm{OH}$ vibrational mode. The chlorite-epidote SWIR spectral absorption features are defined by WV-3 bands 13 through 16 (Fig. 3, chlorite and epidote spectra). To map chlorite and epidote, a band ratio of B14/B16 was used (Fig. 5c). Since dolomite also shows spectral absorption feature near $2.33 \mu \mathrm{m}$ due to $\mathrm{CO}_{3}{ }^{2-}$ vibrational mode, this band ratio can map dolomitic rocks in the study area as well.

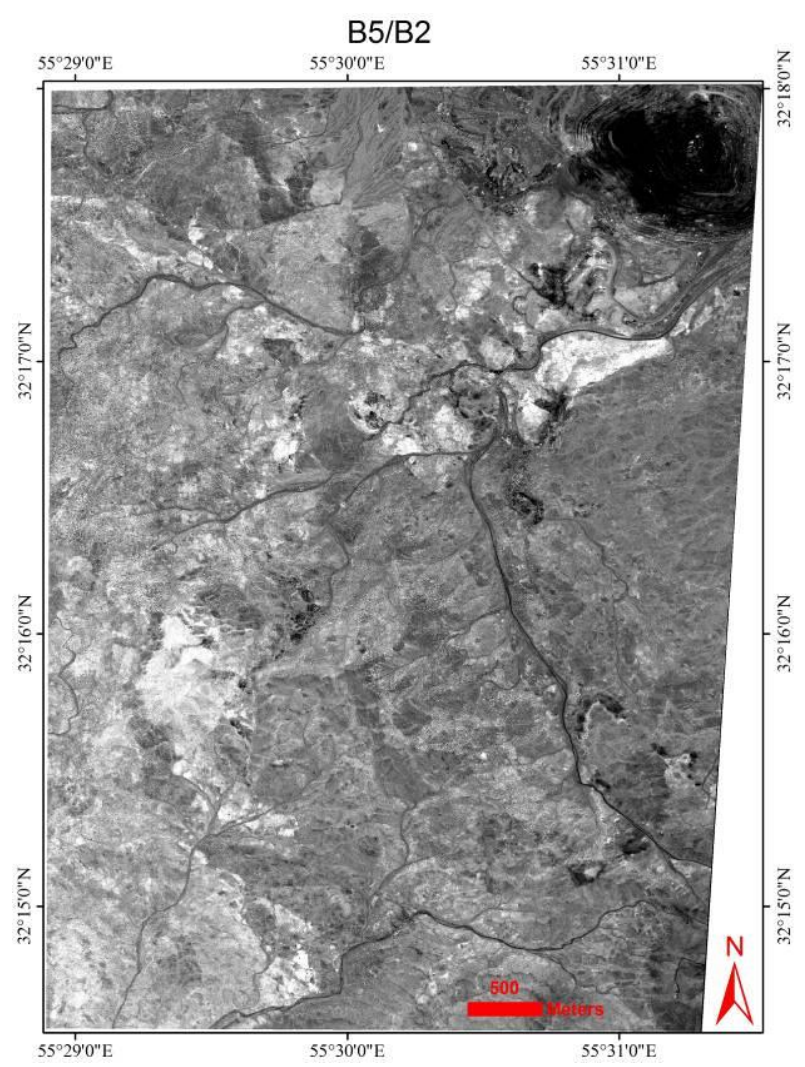

Fig. 4. Band 5/band 2 ratio image of WV-3 data from Chadormalu area, central Iran highlighting ferric iron rich and iron oxide/hydroxides components of desert varnish on the granitic rock unit.

\subsection{Alteration mineral mapping}


The defined band ratios were applied on WV-3 VNIR-SWIR data of Chadormalu area and the output images were verified by the spectra of collected rock samples and the geological map.

Field investigations distinguished that the band ratio B5/B2 successfully mapped the goethite, hematite and desert varnish in the Zarigan granite unit (Fig. 4). False-color composite of WV3 VNIR data also showed the same unit in magenta hue (Fig. 7).

High resolution spectra of rock samples and the geological map of the study area indicated that B13/ B9 ratio was able to map ferrous iron-rich rocks such as magnetite at the Chadormalu iron ore mine. Dark dioritic rocks with more iron-rich silicate minerals (such as actinolite and hornblende) at the northwest and center of the study area, and chlorite-rich gneissic granite and schist at the east of study area (Fig. 5a) were also mapped due to the $\mathrm{Fe}^{2+}$ absorption feature. The B13/ B14 ratio sharply recognized hydrothermally altered granitic rocks at the south west of the study area, and sericite rich rocks at the Chadormalu iron ore mine (Fig. 5b). In addition, the alterations along with crushed metamorphosed rocks containing sericite at the south east of the study area show bright color.

The spectra of collected rock samples and the geological map indicated that the B14/B16 ratio can recognize chlorite and epidote rich green schist and dioritic rocks. However, this ratio mapped small area of dolomitic marble at the south east of the study area next to the gneissic granite unite due to overlap of the $\mathrm{Fe}-\mathrm{OH}$ and $\mathrm{Mg}-\mathrm{OH}$ spectral absorption feature with $\mathrm{CO}_{3}{ }^{2-}$ feature (Fig. 5c).

Since the alteration processes in the rocks are an assemblage of minerals, band ratios combinations can produce false-color composite images that highlight various rock types and accompanying alterations. In order to best recognition of the mineralogy in the study area, band ratios that identify sericiterich rocks (B13/B14), ferrous iron-rich rocks (B13/B9), and chlorite-epidote rich rocks (B14/B16) were selected as RGB, respectively (Fig. 6). Field observations and the geological map indicated that, red to orange hues in the false-color composite band ratio image depict sericite-rich hydrothermally altered granite. Moderate amount of red and moderate amount of green makes dark yellow which are correlated with gneissic granite unit and show that the alteration in this rock unit is composed of sericite-rich and ferrous iron-rich minerals. Large amounts of sericite-rich minerals, moderate epidote- and chlorite-rich minerals and low spatial frequencies of ferrous iron-rich minerals makes sharp pink color in the false-color composite band ratio image which is corresponded to albitite granite in the mine and white granite at the center of the study area. Pure green depicts iron ore in the mine. Cyan hues illustrate epidoteand chlorite-rich late Precambrian schist and intrusive diorite; these rock units have also ferrous iron-rich minerals. Quaternary area and water drainages depict the blue to darkblue and purple hues which is due to $\mathrm{Fe}-\mathrm{OH}$ and $\mathrm{Mg}-\mathrm{OH}$ and also Al-OH bonds.
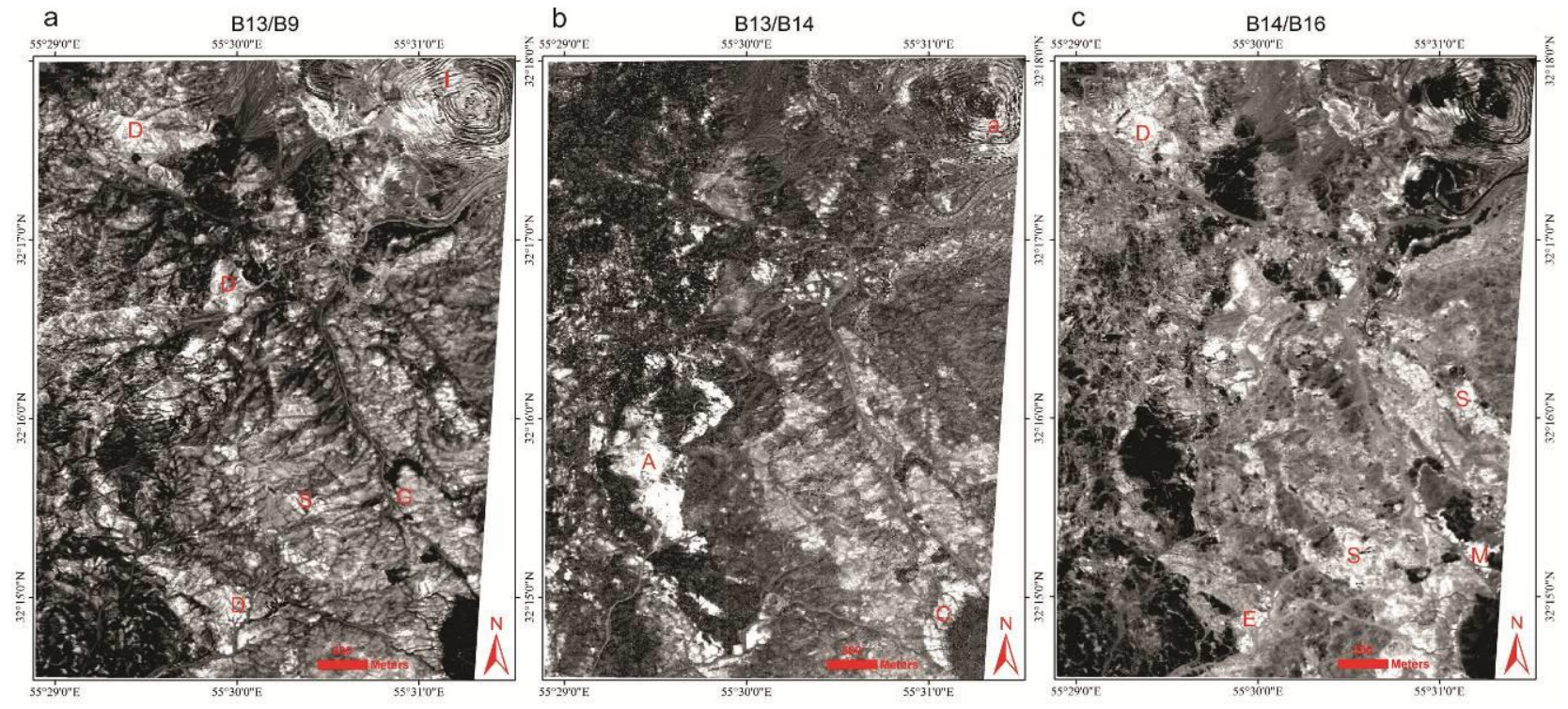

Fig. 5. WV-3 band ratio images of Chadormalu area, central Iran. a. Band 13/band 9 (B13/B9) ratio image highlighting ferrous iron rich rocks including iron ore (I) in the mine, intrusive diorite (D), green schist (S) and gneissic granite (G). b. Band 13/band 14 (B13/B14) ratio image highlighting sericite-rich rocks including albitite granite (a) in the mine, altered granite (A) at the southwest of the study area and alteration along with crushed metamorphosed rocks (C) at the south east of the study area. c. Band 14/band 16 (B14/B16) ratio image highlighting chlorite-epidote rich rocks including intrusive diorite (D), green schist (S) and high Epidotizated rocks (E) at the south part of the study area; Overlap of the Fe-OH and $\mathrm{Mg}-\mathrm{OH}$ spectral absorption feature with $\mathrm{CO}_{3}{ }^{2-}$ spectral absorption feature leads to highlighting dolomitic marble (M) at south east of the study area. 


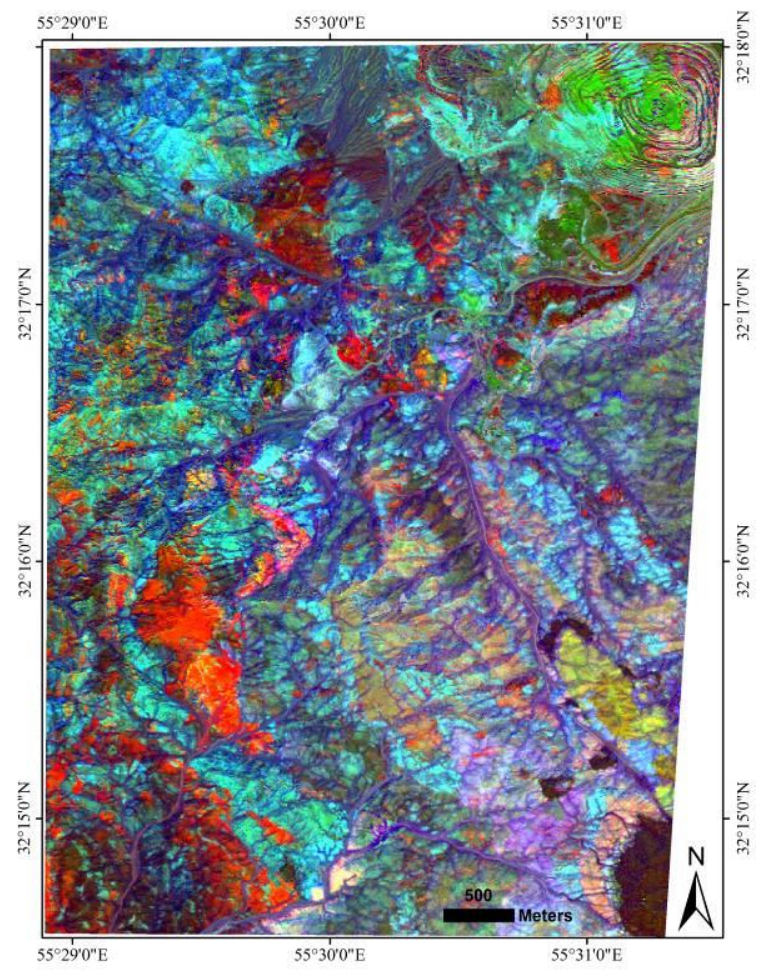

Fig. 6. WV-3 False-color composite $2 \mathrm{~m}$ spatial resolution band ratio image of the Chadormalu area, central Iran. sericite-rich rocks (band 13/band $14=$ red), ferrous iron-rich rocks (band 13/band $9=$ green) and chlorite-epidote rich rocks (band 14/band $16=$ blue) are displayed in the image.

Dark-brown hue in the false-color composite band ratio image illustrates low-reflectance metamorphic rocks including garnet mica schist, quartzite schist and graphite schist. These rocks are comprised of moderate outcrops of sericite-rich minerals and low occurrences of ferrous ironrich minerals.

\subsection{Validation}

The accuracy of produced alteration maps of the study area were assessed by geological map and field observations (Fig. 7). Spectra of the collected rock samples were measured at the spectral laboratory. Spectra of highlighted areas were then compared to the field spectra of known targets to determine if the band ratio is accurately mapping the correct mineral. Each spectrally mapped unit was validated by comparing WV-3 image spectra to sample spectra collected in the field from the same areas. When the resampled spectra of rock units to the WV-3 bands were compared to the image spectra extracted from atmospherically calibrated imagery of same location, it was illustrated that they are very similar. One triplet of spectra from each rock units and accompanying alterations are shown in Fig. 8. A WV-3 spectrum is the mean spectrum from a $2 * 2 \mathrm{~m}$ pixel area while the lab spectrometer measures the field sample spectra with the contact probe, resulting in a probed sample of about $1 \mathrm{~cm}$ in diameter. So spectral curves of WV-3 resampled field sample spectra and WV-3 image spectra show differences in shape.

\section{CONCLUSIONS}

WorldView-3 data have efficient spectral resolution to discriminate alteration minerals with $\mathrm{Fe}^{3+}, \mathrm{Fe}^{2+}, \mathrm{Al}-\mathrm{OH}, \mathrm{Fe}-$ $\mathrm{OH}$ and $\mathrm{Mg}-\mathrm{OH}$ or $\mathrm{CO}_{3}{ }^{2-}$ spectral absorption features. Application of band ratio techniques on WV-3 data successfully discriminated ferrous and ferric iron rich minerals, sericite, epidote, chlorite and dolomite in Chadormalu area. Band 5/band 2 was able to reveal the ferric iron rich minerals such as goethite, hematite and iron oxide/hydroxides components of desert varnish mostly on Zarigan granite. Iron ore in the mine which is mostly composed of magnetite and also chlorite-epidote-rich LatePrecambrian green schist, intrusive diorite and gneissic granite were highlighted as ferrous iron rich minerals using $\mathrm{B} 13 / \mathrm{B} 9$ band ratio. According to $\mathrm{Al}-\mathrm{OH}$ spectral absorption feature at band 14, B13/B14 was proposed to map sericite. The band ratio gray scale image determined that the hydrothermally altered granite and alterations along with crushed metamorphosed rocks are rich of sericite and also iron ore mineralization is closely associated with sericite. Chlorite-epidote-rich Late-Precambrian green schist and intrusive diorite were displayed using B14/B16 ratio. This band ratio also displayed small areas with dolomitic marble. Since the $\mathrm{Fe} / \mathrm{Mg}-\mathrm{OH}$ vibrational mode in chlorite-epidote and $\mathrm{CO}_{3}{ }^{2-}$ in dolomite display their spectral absorption features in WV-3 band 16, the B14/B16 ratio was not successful to separate these minerals.

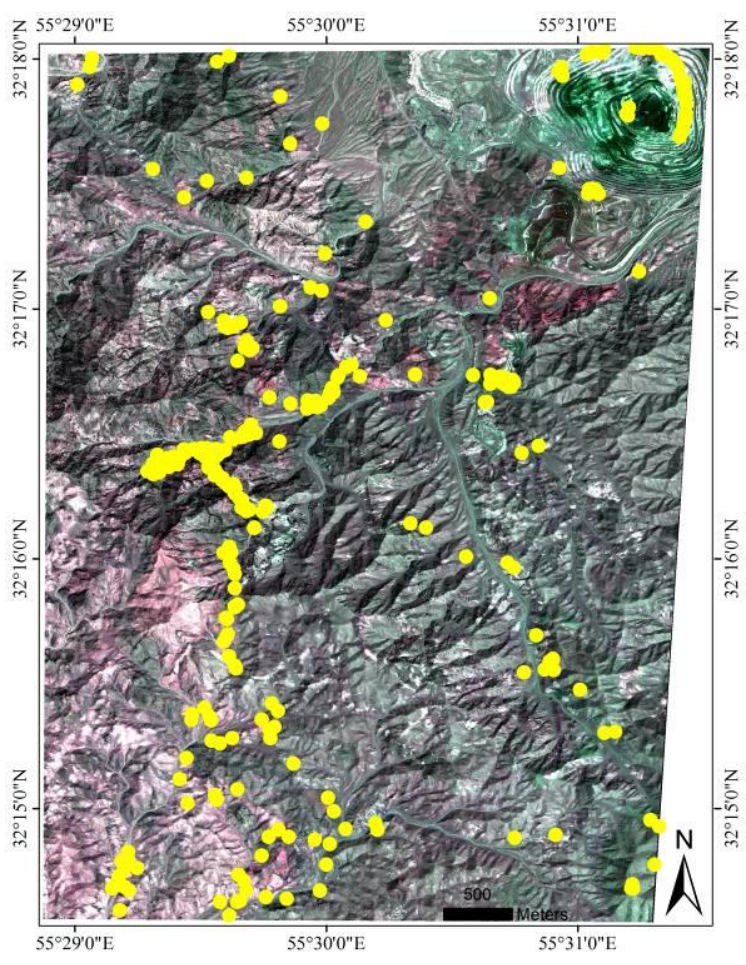

Fig. 7. Field sampling points of the Chadormalu area, central Iran mapped on $2 \mathrm{~m}$ spatial resolution false color composite image of WV-3. Red, green and blue color represent band 5, band 2 and band 3 respectively with the aim of revealing ferric iron and desert varnish in magenta hue which are mostly matched with Zarigan granite unit. 


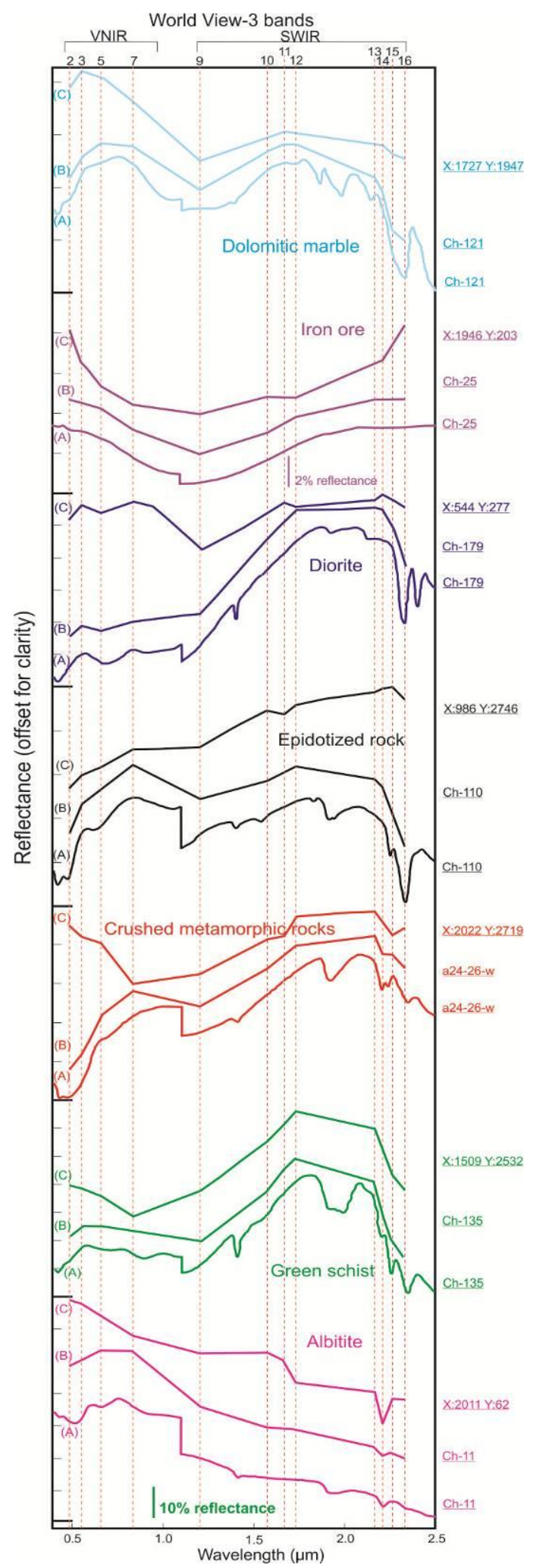

Fig. 8. VNIR-SWIR spectral triplet of (A) high resolution spectra of rock samples from the study area, (B) WV-3

resampled field sample spectra, and (C) WV-3

atmospherically calibrated image spectra from the same study area location of rock units and accompanying alterations.

Dotted lines show positions of WV-3 spectral band centers.

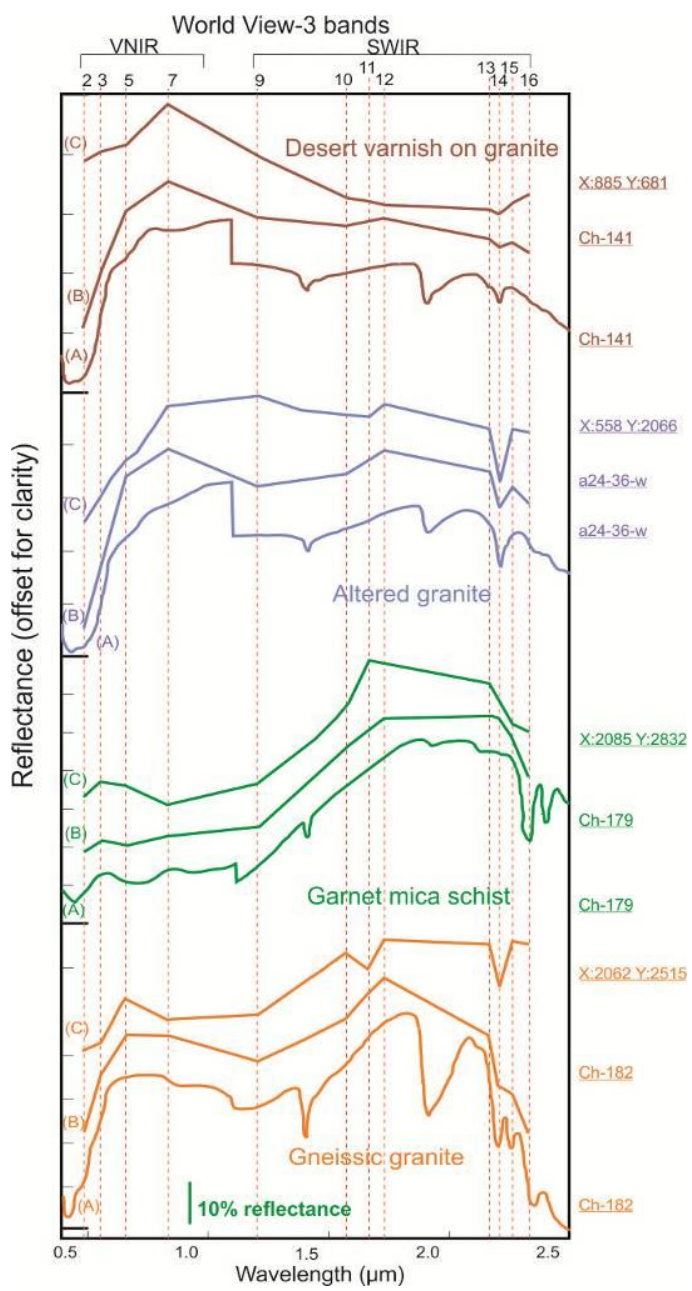

Fig. 8. (Cont.)

The false color composite image produced by band 13/band 14 as red, band 13/band 9 as green and band 14/band 16 as blue successfully discriminated the rock types and accompanying alteration minerals of the study area. High spatial resolution of this data produced large scale map from the study area so that the small areas of rock units were also detected.

Although 1:100000 geological map could not counterbalance the produced mineral map, field observations and high resolution spectra of rock samples validated well the results. This study proved the advantages of spectral and spatial resolution of WorldView-3 in rapid production of detailed alteration and geological maps.

\section{ACKNOWLEDGEMENTS}

The authors would like to thank the Chadormalu Mining and Industrial Company for field logistics and Ms Anna Fonseca, principal geological consultant with SRK Consulting (Canada) Inc., for her kindly supports.

\section{REFERENCES}

Aghanabati A. 1998. Major sedimentary and structural units of Iran (map). J. Geosci., 7, 29-30. 
Baugh, B. and Gow, A., 2018. Separating different rocks with similar spectra using WorldView-3 short wave infrared imagery. GRSG conference, London.

Daliran, F.,Stosch, H.G.,Williams, P., 2009. A review of the Early Cambrian Magmatic and Metasomatic events and their bearing on the genesis of the Fe oxide-REE-apatite deposits (IOA) of the Bafq District, Iran. In:Williams, et al. (Eds.), Smart Science for Exploration and Mining: Proceedings of the $10^{\text {th }}$ Biennial SGA Meeting, Townsville, Australia $17^{\text {th }}$ $20^{\text {th }}$ August 2009.

Digital Globe Inc., 2014. WorldView-3 data sheet. https://www.spaceimagingme.com/downloads/sensors/datash eets/DG_WorldView3_DS_2014.pdf.

Förster, H., Jafarzadeh, A., 1994. The Bafq mining district in Central Iran: a highly mineralized Infracambrian volcanic field. Econ. Geol. 89, 1697-1721.

Ghaemi, F., and Saidi, A., 2006. Geological map of Chadormalu, Geological survey of Iran, Scale 1:100000.

Green, A.A., Craig, M.D., 1985. Analysis of aircraft spectrometer data, with logarithmic residuals. In: Vane, G., Goetz, A. (Eds.), Proceedings of the Airborne Imaging Spectrometer Data Analysis Workshop. JPL, 111-119.

Hewson, R., Van Der Werff, H., Usman, M., Van Der Meer, F., Taranik, D., Baugh, B., 2018. WorldView-3: Evaluation of Its Mineral Mapping Capability at Rodalquilar, Spain. GRSG conference, London.

Hunt, G.R., 1977. Spectral signatures of particulate minerals in the visible and near infrared. Geophysics, 42, 501-513.

Hunt, G.R., Salisbury, J.W., Lenhoff, C.R., 1972. Visible and near-infrared spectra of minerals and rocks: V. Halides, phosphates, arsenates, vanadates, and borates. Modern Geology, 3, 121-132.

Johnson, K.E., and Koperski, K., 2017. WorldView-3 SWIR land use-land cover mineral classification: Cuprite, Nevada. Pecora 20 Conference-Observing a Changing Earth; Science for Decisions- Monitoring, Assessment, and Projection. 7 P.

Karimzadeh, Z., Tangestani, M. H., 2018. Identification of hydrothermal alteration mineralogy from Chadormalu Iron deposit area, Yazd province, Iran, through reflectance spectroscopy and petrographic data. The first national conference of Iranian Geological Remote Sensing Society (IGRSS), 12-14 th Dec. 2018, Kerman-Iran (in Persian with English abstract). https://www.civilica.com/Paper-IGRSS01IGRSS01_004.html

Kruse, F. A., Perry, S.L., 2013. Mineral mapping using simulated WorldView-3 short-wave infrared imagery. Remote Sens., 5 (6), 2688-2703.

Kruse, F. A., William M. Baugh, W. M., Perry, S. L., 2015. Validation of Digital Globe WorldView-3 Earth imaging satellite shortwave infrared bands for mineral mapping, Journal of Applied Remote Sensing, 9, 17 p.
Kuester, M., 2016. Radiometric Use of WorldView-3 Imagery. Digital Globe, Technical Note, $12 \mathrm{p}$.

Majidi, J., Babakhani, A. R., 2000. Geological map of Ariz, Geological survey of Iran, Scale 1:100000.

Mars, J. C., 2018. Mineral and Lithologic Mapping Capability of WorldView 3 Data at Mountain Pass, California, Using True- and False-Color Composite Images, Band Ratios, and Logical Operator Algorithms. Econ. Geol., 113, 1587-1601.

Mather, P.M., 2004. Image transforms, Computer processing of remotely-sensed images; an introduction. 3rd ed.: Chichester, John Wiley \& Sons Ltd, p.136-179.

Miguel-Ayanz, J. S., Biging, G. S., 1996. An iterative classification approach for mapping natural resources from satellite imagery. International Journal of Remote Sensing, 17, 957-981.

Ramezani, J., Tucker, R.D., 2003. The Saghand region, central Iran: $\mathrm{U}-\mathrm{Pb}$ geochronology, petrogenesis and implications for Gondwana tectonics. Am. J. Sci., 303, 622665.

Rowan, L.C., and Mars, J.C., 2003. Lithologic mapping in the Mountain Pass, California, area using Advanced Spaceborne Thermal Emission and Reflection Radiometer (ASTER) data. Remote Sensing of Environment, 84, 350366.

Salehi, T., Tangestani, M. H., 2018. Large-scale mapping of iron oxide and hydroxide minerals of Zefreh porphyry copper deposit, using WorldView-3 VNIR data in the Northeastern Isfahan, Iran. Int J Appl Earth Obs Geoinformation, 73, 156169.

Sun, Y., Tian, S., Di, B., 2017. Extracting mineral alteration information using WorldView-3 data. Geosci. Front., 8, 1051-1062.

Torab, M. F., 2008. Geochemistry and metallogeny of magnetite apatite deposits of the Bafq Mining District, Central Iran, PhD thesis. Clausthal University of Technology, $144 \mathrm{p}$.

Vincent, R.K., 1997. Fundamentals of geological and environmental remote sensing. Upper Saddle River, New Jersey, Prentice Hall, 366 p.

Ye, B., Tian, S., Ge, J., Sun, Y., 2017. Assessment of WorldView-3 Data for Lithological Mapping. remote sensing, 9, 1132. 